\title{
DEVELOPMENT OF CEMENT FOR GEOTHERMAL WELLS
}

\author{
FINAL REPORT
}

\author{
GeORGE L. KaLOUSEK \\ Colorado School of Mines \\ Golden, Colorado 80401
}

March 1, 1979

WORK PERFORMED FOR THE

DIVISION OF GEOTHERMAL ENERGY

U.S. DEPARTMENT OF ENERGY

WASHINGTON, D.C. 20545

\section{L.E. KUKACKA, Project Leader}

PROCESS SCIENCES DIVISION

DEPARTMENT OF ENERGY AND ENVIRONMENT

\section{BROOKHAVEN NATIONAL LABORATORY \\ UPTON, NEW YORK 11973}

This report was prepard as an account of work sponsored by the United States Government. Neither the United States nor the United States Department of

Energy, nor any of their employees, nor any of their

contractors, subcontractors, or their employees, makes any wartanty, express or implied, or assumes any legal

liability or responsibility for the accuracy, completeness

or usefulness of any information, apparatus, product or

process disclosed, or represents that its use would not

infringe privately owned rights.

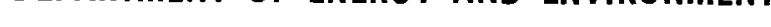




\section{DISCLAIMER}

This report was prepared as an account of work sponsored by an agency of the United States Government. Neither the United States Government nor any agency Thereof, nor any of their employees, makes any warranty, express or implied, or assumes any legal liability or responsibility for the accuracy, completeness, or usefulness of any information, apparatus, product, or process disclosed, or represents that its use would not infringe privately owned rights. Reference herein to any specific commercial product, process, or service by trade name, trademark, manufacturer, or otherwise does not necessarily constitute or imply its endorsement, recommendation, or favoring by the United States Government or any agency thereof. The views and opinions of authors expressed herein do not necessarily state or reflect those of the United States Government or any agency thereof. 


\section{DISCLAIMER}

Portions of this document may be illegible in electronic image products. Images are produced from the best available original document. 


\section{NOT I C E}

This report was prepared as an account of work sponsored by the United States Government. Neither the United States nor the United States Department of Energy (DOE), nor any of their employees, nor any of their contractors, subcontractors, or their employees, makes any warranty, express or implied, or assumes any legal liability or responsibility for the accuracy, completeness or usefulness of any information, apparatus, product or process disclosed, or represents that its use would not infringe privately owned rights.

Printed in the United States of America

Available from

National Technical Information Service

U.S. Department of Commerce

5285 Port Royal Road

Springfield, VA 22161

Price: Printed Copy $\$ 4.50$; Microfiche $\$ 3.00$

June 1979

680 copies 
In the present research, modifications of portland cement-silica and $\mathrm{BC}_{2} \mathrm{~S}-$ silica cements were studied at $150^{\circ}$ to $350^{\circ} \mathrm{C}\left(302^{\circ}\right.$ to $\left.662^{\circ} \mathrm{F}\right)$ and saturated steam pressure. Emphasis was on relating the chemistry of the cements to their properties. Particular attention was given to long-term strength, bond strength, and effects of weight-reducing agents. The effects of $\mathrm{Al}_{2} \mathrm{O}_{3}, \mathrm{Fe}_{2} \mathrm{O}_{3}, \mathrm{SO}_{3}, \mathrm{Na}_{2} \mathrm{CO}_{3}$, and $\mathrm{Na}_{2} \mathrm{SO}_{4}$ on different binders were studied, and were found to range from deleterious to beneficial. Aluminous tobermorite (A-Tobermorite), xonotlite, and truscottite were dominant ultimate binders. The present results and others indicate that truscottite may undergo serious strength retrogression upon longterm exposure. A-Tobermorite was stable to $250^{\circ} \mathrm{C}\left(472^{\circ} \mathrm{F}\right)$ or higher. Xonotlite exhibited a wide range in strength, and some 1 imited evidence suggests that it too may undergo strength retrogression. No insurmountable difficulties were encountered with normal-weight cements, but light-weight cements posed some questions. With the problems at their current stage of definition, further research should be rewarding.

\section{ACKNONLEDGMENTS}

Grateful acknowledgments are made to Kurt Mitchell for conducting the tests including development of test procedures, to the Bureau of Reclamation for providing high pressure test vessels and other facilities, and to Dowell. Division, Dow Chemical U.S.A. for thickening time tests. Special acknowledgment is made to Professor H.F.W. Taylor of Aberdeen University for phase identification of selected cements and special preparations. One report of his work is pending publication and a second is being finalized for publication. 


\section{INTRODUCTION}

This report describes laboratory research on cements for firmly anchoring a steel casing to the formation (wallrock) in wells operating at high temperature. Particular attention was given to potential cements for geothermal wells. The candidates were modifications of portland and beta dicalcium silicate cements with a variety of additions. Curing was at $150^{\circ}$ to $350^{\circ} \mathrm{C}\left(302^{\circ}\right.$ to $662^{\circ} \mathrm{F}$ ) and saturated steam pressure. Emphasis was on identification of the hydrous calcium silicates and their relation to physical properties.

Physical testing included determination of thickening time, early and later strengths, volume change, cement-formation and cement-steel bonds, compressive strength of cement-formation sand specimens, saline water resistance, and permeability. X-ray diffraction and other means were applied for phase identification. Results of previous studies on calcium silicate hydrates at the Colorado School of Mines1-6 served as background for this study. The science and technology of cements for oil and gas wells have been described; ; and suggested aspects of geothermal well cements needing research include bond strength, long-term strength, and effects of slurry-weight reducing additions.

Cements for oil and gas wells and geothermal wells serve over a large temperature range, part of which is common to both types of cementing. The oilwell finishing technology al ready developed is applicable to geothermal cementing over the common temperature range. Conversely, new information on goethermal cementing should benefit the oil-well finishing technology. The more severe conditions of geothermal wells higher temperatures and pressures, strongly corrosive saline waters, and fragile formations dictate development of improved technologies.

Portland cement as such has been successfully used at temperatures up to about $120^{\circ} \mathrm{C}\left(247^{\circ} \mathrm{F}\right)$. At higher temperatures $\alpha \mathrm{C}_{2} \mathrm{SH}$, * a very weak binder, is formed. Addition of silica to the cement to reduce the aross $\mathrm{C} / \mathrm{S}$ ratio to about 0.8 effectively prevented the cement deterioration. Tobermorite, a strong binder and stable up to $150^{\circ} \mathrm{C}\left(302^{\circ} \mathrm{F}\right)$, is formed at the expense of the $\alpha \mathrm{C}_{2} \mathrm{SH}$. It is formed initially from a wide range of $\mathrm{C} / \mathrm{S}$ compositions and is transformed at higher temperatures according to the reaction.

$$
\begin{gathered}
\text { tobermorite } \stackrel{150^{\circ} \mathrm{C}}{\longrightarrow} \text { xonotlite }+ \text { gyrolite } \stackrel{220^{\circ} \mathrm{C}}{\longrightarrow} \text { xonotlite + truscottite }, \\
\stackrel{?^{\circ} \mathrm{C}}{\longrightarrow} \text { xonotlite }+ \text { silica. }
\end{gathered}
$$

Other phases including scawtite, $\operatorname{CSH}(1)$ and "3.15 A phase"9 may also form. Scawtite, $\mathrm{C}_{7} \mathrm{~S}_{6} \overline{\mathrm{CH}}_{2}$, at $150^{\circ}$ to $300^{\circ} \mathrm{C}\left(302^{\circ}\right.$ to $\left.572^{\circ} \mathrm{F}\right)$ replaces xonotlite partially or totally in the equilibrium, depending on the amount of $\mathrm{CO}_{2}$ in the cement 5 . The presence of components extraneous to the system $\mathrm{C}-\mathrm{S}-\mathrm{H}$, such as $\mathrm{Al}_{2} \mathrm{O}_{3}, \mathrm{Fe}_{2} \mathrm{O}_{3}$,

*The abbreviated formulas of cement chemistry are used: $\mathrm{CaO}=\mathrm{C}, \mathrm{Ca}(\mathrm{OH})_{2}=\mathrm{CH}$,

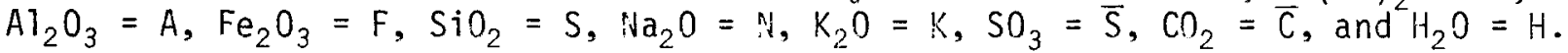


$\mathrm{SO}_{3}, \mathrm{Na}_{2} \mathrm{O}, \mathrm{K}_{2} \mathrm{O}$, etc., may have either beneficial or deleterious affects as shown previously 1,6 and in this study. The extraneous components may originate from the portland cement, deliberate additions, drilling mud, formation, or saline ground waters.

The dicalcium silicate-silica cement, Class $\mathrm{J}$, which contains a minimal amount of extraneous components, was selected because (1) the exact "tailoring" of the compositions of the phases with extraneous components would be facilitated, and (2) the control of the thickening time without additions or with minimal ones would be more readily realized. The use of organic additions to control the thickening time was held to a minimum.

The principal objectives of the research were (1) to develop cement of improved properties, and (2) to determine the cause of poor performance and find ways to correct it.

\section{MATERIALS}

The starting materials were Class $\mathrm{G}$ portland cement, $\mathrm{Cl}$ ass $\mathrm{J}$ cement $(69 \%$ $\mathrm{BC}_{2} \mathrm{~S}$ and $31 \%$ quartz computed from oxide analysis), and quartz as tripoli, silica flour, or sand. The extraneous components were $\mathrm{Al}_{2} \mathrm{O}_{3}$ as gibbsite (or infrequently kaolinite), $\mathrm{Fe}_{2} \mathrm{O}_{3}$ as goethite, $\mathrm{SO}_{3}$ as gypsum, and $\mathrm{Na}_{2} \mathrm{O}$ and $\mathrm{K}_{2} \mathrm{O}$ as hydroxide or sulfate. Other additions, particularly extenders, were perlite, bentonite, powdered coal, sepiolite, flyash, gilsonite, etc.

The principal parameter in proportioning the raw mix was the molar $\mathrm{C} / \mathrm{S}$ ratio. Alumina was added as a replacement for $\mathrm{SiO}_{2}$, one $\mathrm{Al}^{3+}$ for one $\mathrm{Si}^{4+}$. Class $G$ cement is normaliy used with addition of $4.0 \% \mathrm{SiO}_{2}$ by weight of cement (71\% cement: $29 \%$ silica). The $\mathrm{C} / \mathrm{S}$ ratio of this mix was 1.06 , and the $\mathrm{Ca} /(\mathrm{Si}+\mathrm{Al})$ ratio was 0.98 . For simplicity, this composition is designated 1.0 C/S-G. Cement $G$ was also modified to 0.6 and $0.3 \mathrm{C} / \mathrm{S}$ by addition of silica. The $\mathrm{Cl}$ ass $\mathrm{J}$ cement had a $\mathrm{C} / \mathrm{S}$ ratio of 0.85 based on oxide composition. The composition was modified to $1.0 \mathrm{C} / \mathrm{S}$ by addition of reagent quality $\mathrm{Ca}(\mathrm{OH})_{2}$ and to $0.6,0.65$, and 0.70 by addition of silica. The silica in most compositions for physical property measurements was added as silica sand of the type used in field cements . The composition $0.60 \mathrm{C} /(\mathrm{S}+3 \mathrm{~A})$ designates $3.0 \%$ addition of $\mathrm{Al}_{2} \mathrm{O}_{3}$ by weight of total mix as replacement for $\mathrm{SiO}_{2}$. Otherwise, the additions, especially extenders, were added by weight of the cement. For uniformity, the additions to the modified $\mathrm{Class} \mathrm{J}$ cement were made by weight of the $\mathrm{BC}_{2} \mathrm{~S}$ in the cement as received.

The mixes were formed by mixing the dry ingredients thoroughly and then adding water to form readily pourable slurries. Normal-weight slurries even with moderate amounts of extenders weighed about 15.0 to $16.51 \mathrm{~b} / \mathrm{gal}$ (112 to $124 \mathrm{lb} / \mathrm{ft}^{3}$ ), and 1 ight-weight extended slurries weighed about 11 to $13 \mathrm{lb} / \mathrm{gal}$ (82 to $97 \mathrm{lb} / \mathrm{ft}^{3}$ ). The normal-weight slurries were mixed manually for 5 min, and the light-weight slurries were mixed in a l-liter Waring blender according to API Standard RPIOB. The slurry density was measured at $23^{\circ} \mathrm{C}\left(73^{\circ} \mathrm{F}\right)$ with a calibrated pycnometer.

The slurries were cast into 1 - or 2-in. cubes into $1 \times 1 \times 5-i n$. bars provided with stainless steel reference points for length measurements, and into assemblies for bond strength measurement. Precuring was at $150^{\circ} \mathrm{C}\left(302^{\circ} \mathrm{F}\right)$ for $24 \mathrm{hr}$ in saturated steam; some Class $\mathrm{G}$ cement specimens were preset at $23^{\circ} \mathrm{C}\left(73^{\circ} \mathrm{F}\right)$ for 
1 or 2 days in moist air and then autoclaved at temperatures up to $350^{\circ} \mathrm{C}\left(662^{\circ} \mathrm{F}\right)$ and saturated steam pressure. The most commonly used temperatures were $175^{\circ}$, $250^{\circ}, 300^{\circ}$, and $345^{\circ} \mathrm{C}\left(346^{\circ}, 482^{\circ}, 572^{\circ}\right.$, and $\left.653^{\circ} \mathrm{F}\right)$.

The bond-strength mold assemblies consisted of a 2-in. by $1-i n$. deep mild steel ring and a mild steel base plate. A 1/8-in. deep by 3/4-in. diam recess was machined in the center of the base plate for accurately centering a $3 / 4$-in. diam by 2-in. long specimen of either a mild steel or rock. The base plate was carefully centered and firmly sealed to the ring to prevent water loss. The annulus of the assembly was then filled with the slurry. A tightly fitting cover recessed to fit snugly over the ring completed the assembly. After autoclaving, the top and base plates were carefully removed. The specimen was placed on a bearing plate of the tester provided with an opening slightly over $3 / 4 \mathrm{in}$. in diameter into which the protruding end of the specimen fitted snugly but not tightly. Load to break the bond was applied and recorded in psi of the contact area of specimen and cement annuilus.

All specimens of the study after curing were equilibrated in $23^{\circ} \mathrm{C}\left(73^{\circ} \mathrm{F}\right)$ water before testing.

Besides having their physical properties determined, many of the specimens were examined by $\ddot{x}$-ray diffraction for phase identification.

Some auxiliary specimens, cast in 1/2xi-1/4-in. stainless steel foil receptacles and cured in a 20-m? autoclave, were made for detailed studies on the phases. Many of these were examined by Taylor with an x-ray diffractometer, Guinier powder camera, and other means. Besides the chemical terms given above in a footnote, the following abbreviations are used in this report: $B=$ bentonite, $F . A .=$ flyash, Gil. = gilsonite, $G($ or Gyp $)=$ gypsum, $P($ or Perl $)=$ perlite, Sep. = sepiolite, the $\mathrm{C} / \mathrm{S}$ is omitted in formulas where space is limited; for example, $1.0 \mathrm{C} / \mathrm{S}-\mathrm{G}$ is given as $1.0-G$, and Cement $\mathrm{Cl}$ ass $\mathrm{G}$ or $\mathrm{J}$ as part of a composition is reported as $-G$ or $-J$.

\section{RESULTS}

\section{A. Strength}

The compressive strengths of the Class $G$ and Class $J$ cements plus silica and modifications were generally satisfactory. Some results on the light-weight cements were questionable and a few were unsatisfactory. Factors such as degree of precuring, size of cube, and others were considered when questions arose.

Determination of long-term strengths was recognized as an important objective, but the scope of the investigation and the limited facilities precluded its accomplishment. As mentioned, the mix compositions were generally restricted to those of truscottite $(0.6 \mathrm{C} / \mathrm{S})$, tobermorite $(0.83 \mathrm{c} / \mathrm{S})$, and xonotlite $(1.0$ $\mathrm{C} / \mathrm{S})$. Curing was done in an attempt to obtain the equilibrium binder in a short time by resorting to the higher temperatures at the upper limit of the stability range of the phase or even slightly higher. The equilibrium phase at the higher temperature would be the same as the phase obtained in a long time at the lower temperatures of the stability range. The long-term strength of the equilibrium phase would be the same as the strength obtained in a short time provided crystal growth did not occur. The effect of crystal growth and crystal size dis- 
tribution on strength has been previously considered ${ }^{10-12}$.

Representative strength results for normal-weight $1.0 \mathrm{C} / \mathrm{S}-\mathrm{G}$ cement are given in Table 1 which shows the effects of two salts, moderate amounts of extenders, degree of precure, and cube size. Satisfactory strengths, 1000 ps $i$ $(6890 \mathrm{kPa})$ or higher, were obtained except on specimens containing perlite and bentonite and precured at $23^{\circ} \mathrm{C}\left(73^{\circ} \mathrm{F}\right)$. Specimens containing both flyash and bentonite had unsatisfactory strengths at $150^{\circ}$ and $345^{\circ} \mathrm{C}\left(302^{\circ}\right.$ and $\left.653^{\circ} \mathrm{F}\right)$. The striking feature was the very high strength, 10,000 to 13,000 psi $(68,900$ to $89,570 \mathrm{kPa}$ ) of the $1.0 \mathrm{C} / \mathrm{S}-\mathrm{G}$ with and without additions of $\mathrm{NaCl}$, gypsum, or gilsonite. The extenders, even in moderate amounts, caused large reductions. Both precures generally gave about the same result. The $1-i n$. cubes in this and other series were invariably weaker than the $2-i n$. cubes at $150^{\circ} \mathrm{C}\left(302^{\circ} \mathrm{F}\right)$. At other temperatures, the differences were relatively small.

The very high strengths of specimens without extenders except gilsonite at $345^{\circ} \mathrm{C}\left(653^{\circ} \mathrm{F}\right)$ with xonotlite as binder were unexpected. The $150^{\circ} \mathrm{C}\left(302^{\circ} \mathrm{F}\right)$ results on the other hand were generally much lower for the $1.0 \mathrm{C} / \mathrm{S}-\mathrm{G}$ cements than for the $1.0 \mathrm{C} / \mathrm{S}-\mathrm{J}$ cements (Table 2). The binders of the $1.0 \mathrm{C} / \mathrm{S}-\mathrm{G}$ cements were $a \mathrm{C}_{2} \mathrm{SH}$ and $\mathrm{CSH}(1)^{2}$ of superior strength. The $150^{\circ} \mathrm{C}\left(302^{\circ} \mathrm{F}\right)$ binders in the Class $\mathrm{J}$ cements were either tobermorite or $\mathrm{CSH}(1)$. The high strengths of the $1.0 \mathrm{C} / \mathrm{S}-\mathrm{G}$ cements at $345^{\circ} \mathrm{C}\left(653^{\circ} \mathrm{F}\right)$ were not readily explained, but the extraneous constituents from the portland cement were suspect. This prompted a study of $1.0 \mathrm{C} / \mathrm{S}-\mathrm{J}$ compositions with various combinations of additions of $\mathrm{Al}_{2} \mathrm{O}_{3}$ ? $\mathrm{Fe}_{2} \mathrm{O}_{3}$, and $\mathrm{SO}_{3}$ (Table 2). It is concluded that the extraneous components, as such, were not responsible for the high $345^{\circ} \mathrm{C}\left(653^{\circ} \mathrm{F}\right)$ strengths. The $150^{\circ} \mathrm{C}\left(302^{\circ} \mathrm{F}\right)$ 1.) $\mathrm{C} / \mathrm{S}-\mathrm{J}$ cements were generally much stronger than the $1.0 \mathrm{C} / \mathrm{S}-\mathrm{G}$ cements. To facilitate comparison of these two cements with and without extenders, the results are summarized in Figure 1. In the $\mathrm{Cl}$ ass $\mathrm{J}$ cements, scawtite, depending on the amount of $\mathrm{CO}_{2}$ in the cement, partially replaced xonotlite in the equilibria. The effect of this phase remains to be determined.

The strengths of $0.7 \mathrm{C} /\left(\mathrm{S}+0.0\right.$ to $\left.7.5 \% \mathrm{~A}_{\mathrm{A}}\right)-\mathrm{J}$ and the $0.5,0.3$, and $1.0 \mathrm{C} / \mathrm{S}-\mathrm{G}$ cements are compared in Figure 2. The $0.7 \mathrm{C} /(\mathrm{S}+\mathrm{A})-\mathrm{J}$ are representative of the other $\mathrm{J}$ cements having compositions of 0.6 to $0.83 \mathrm{C} / \mathrm{S}+\mathrm{A}$. Note especially the curing at $250^{\circ} \mathrm{C}\left(482^{\circ} \mathrm{F}\right)$. The data in Fiqure 2 for the 23 -day cure. It had already been established that A-Tobermorite formed well developed crystais in 7 days or less at $250^{\circ} \mathrm{C}\left(482^{\circ} \mathrm{F}\right)$. The crystals at 7 days as revealed by $x$-ray diffraction were the same as at 28 days, and the strengths at the two ages were nearly the same. This led to the tentative conclusion that the 7- to 28-day results were suitable for predicting the long-term strength of A-Tobermorite. Curing at $300^{\circ} \mathrm{C}\left(572^{\circ} \mathrm{F}\right)$ in comparison tests caused reduction in strength. In later tests, curing at $300^{\circ} \mathrm{C}\left(572^{\circ} \mathrm{F}\right)$ was replaced by curing at $175^{\circ} \mathrm{C}\left(346^{\circ} \mathrm{F}\right)$. The low strengths of the $0.7 \mathrm{C} /(\mathrm{S}+\mathrm{A})$ compositions were atypical. Inorganic accelerators overcame this weakness.

The $0.6,0.8$, and $1.0 \mathrm{C} / \mathrm{S}-\mathrm{G}$ had high strengths at $259^{\circ} \mathrm{C}\left(572^{\circ} \mathrm{F}\right)$ and $345^{\circ} \mathrm{C}$ $\left(653^{\circ} \mathrm{F}\right)$. The binder consisted of xonotlite plus residual quartz for the 0.6 and $0.8 \mathrm{C} / \mathrm{S}$ compositions and xonotlite alone for the $1.0 \mathrm{c} / \mathrm{S} \mathrm{mix}$. The binder at $150^{\circ} \mathrm{C}\left(302^{\circ} \mathrm{F}\right)$ was $\alpha \mathrm{C}_{2} \mathrm{SH}$ and $\mathrm{CSH}(1)$.

Representative strengths of the $0.85 \mathrm{C} / \mathrm{S} \mathrm{Class} \mathrm{J}$ cement with and without moderate additions of extenders and at normal weight are shown in Table 3 . All strengths were satisfactory including that with addition of flyash. The introduction of $7 \% \mathrm{Al}_{2} \mathrm{O}_{3}$ plus $\mathrm{Ca}(\mathrm{OH})_{2}$ to maintain the $\mathrm{C} /(\mathrm{S}+\mathrm{A})$ at 0.35 illustrates 
Table 1

Compressive Strengths of $1.0 \mathrm{C} / \mathrm{S}-\mathrm{G}$ Cements

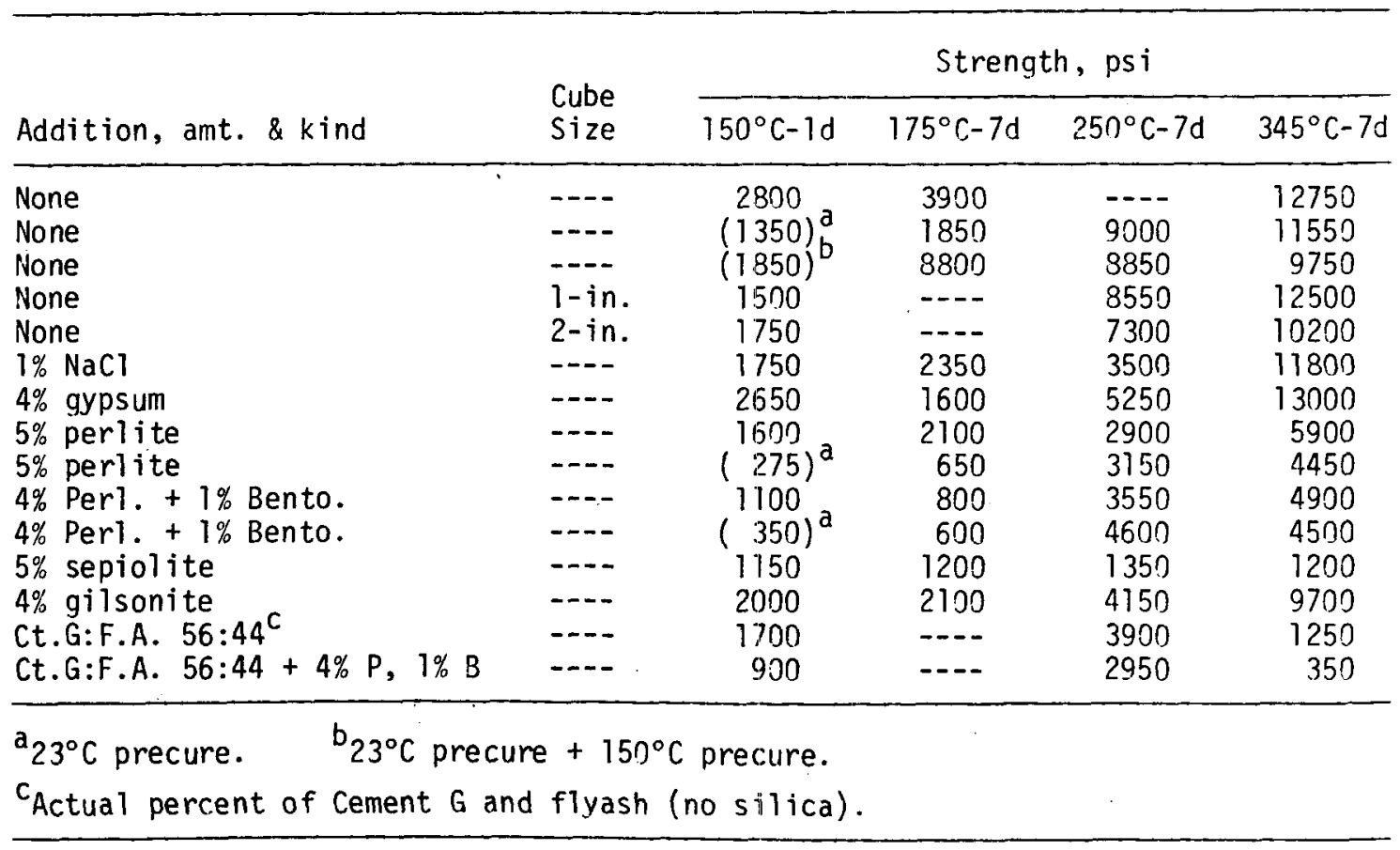

\begin{tabular}{|c|c|c|c|c|}
\hline \multicolumn{5}{|c|}{ Table 2} \\
\hline \multirow[b]{2}{*}{ Addition, Amt. \& kind } & \multicolumn{4}{|c|}{ Strength, psi } \\
\hline & $150^{\circ} \mathrm{C}-1 \mathrm{~d}$ & $175^{\circ} \mathrm{C}-7 \mathrm{~d}$ & $250^{\circ} \mathrm{C}-7 \mathrm{~d}$ & $345^{\circ} \mathrm{C}-7 \mathrm{~d}$ \\
\hline $\begin{array}{l}\text { None } \\
3 \% A-11 \% F \\
3 \% A-2 \% F \\
0 \% A-2 \% F \\
0 \% A-4 \% F \\
0 \% A-4 \% F \\
4 \% A-0 \% F \\
4 \% A-2 \% F \\
4 \% A-4 \% F \\
4 \% A-6 \% F \\
3 \% A-2 \% \text { NaCl } \\
3 \% A-4 \% \text { gypsum } \\
3 \% A-4 \% P, 2 \% B \\
\text { Same, } 2 \text { A r run }\end{array}$ & $\begin{array}{l}4600 \\
6300 \\
7900 \\
9800 \\
7600 \\
5600 \\
6000 \\
5500 \\
5500 \\
4100 \\
5350 \\
1700 \\
1500\end{array}$ & $\begin{array}{l}6200 \\
5400 \\
5600 \\
9500 \\
8700 \\
7200 \\
7100 \\
5500 \\
5800 \\
3100 \\
4000 \\
2200 \\
1750\end{array}$ & $\begin{array}{l}2750 \\
8200 \\
6400 \\
3600 \\
4000 \\
6200 \\
6200 \\
5200 \\
6100 \\
4350 \\
5950 \\
2150 \\
1500\end{array}$ & $\begin{array}{l}4300 \\
7450 \\
4400 \\
5500 \\
5250 \\
3500 \\
3100 \\
3200 \\
3450 \\
2250 \\
2550 \\
1500 \\
1300\end{array}$ \\
\hline
\end{tabular}




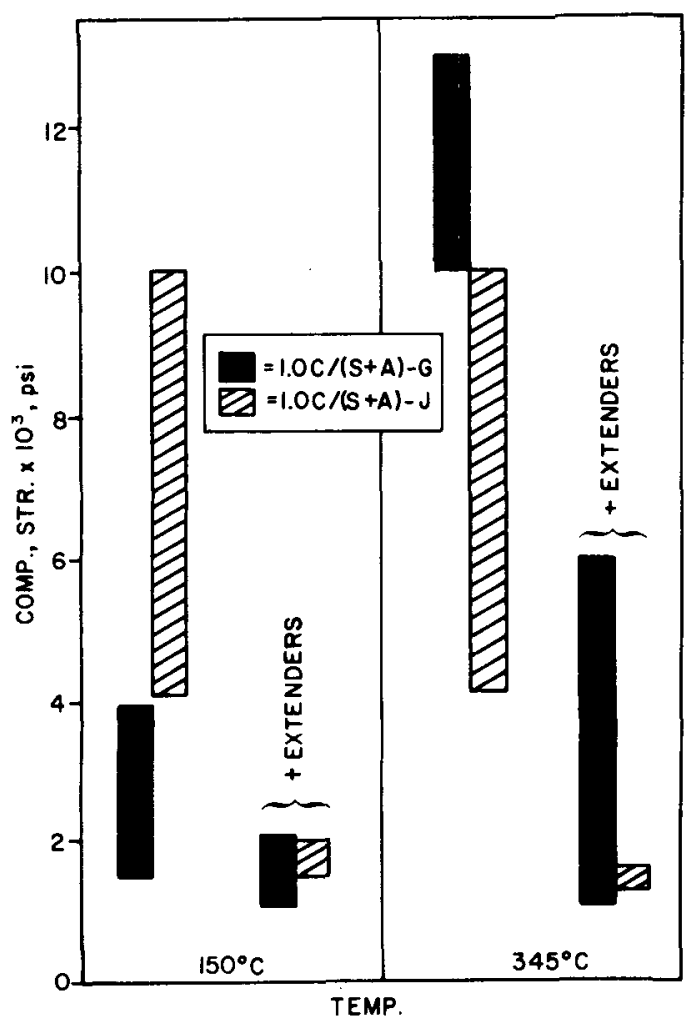

Figure 1. Summary of strengths of $1.0 \mathrm{c} / \mathrm{S}-\mathrm{J}$ and $1.0 \mathrm{c} / \mathrm{S}-\mathrm{G}$ cements.

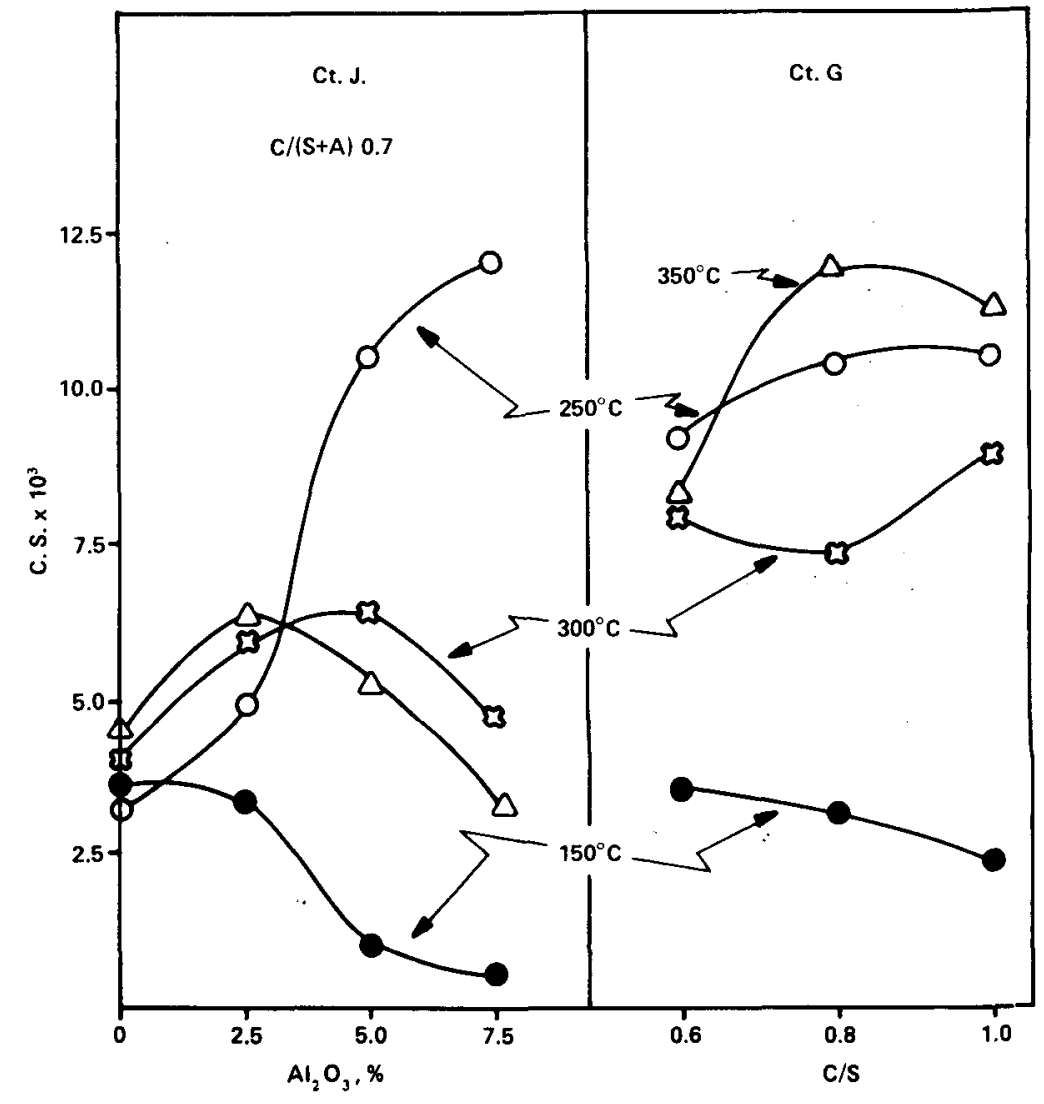

Figure 2. Strengths of $0.7 \mathrm{C} /(\mathrm{S}+\mathrm{A})-\mathrm{J}$ and $0.6,0.8$, and $1.0 \mathrm{c} / \mathrm{S}-\mathrm{G}$ cements.

Table 3

Compressive Strengths of Class $\mathrm{J}$ Cement

\begin{tabular}{lcccc}
\hline & \multicolumn{4}{c}{ Strenqth, psi } \\
\cline { 2 - 5 } Addition, amt. \& kind & $150^{\circ} \mathrm{C}-1 \mathrm{~d}$ & $175^{\circ} \mathrm{C}-7 \mathrm{~d}$ & $250^{\circ} \mathrm{C}-7 \mathrm{~d}$ & $345^{\circ} \mathrm{C}-7 \mathrm{~d}$ \\
\hline None & 2500 & 5800 & 7000 & 4800 \\
$7 \% \mathrm{Al}_{2} \mathrm{O}_{3}$ & 4600 & 8500 & 8000 & 7900 \\
$5 \%$ perlite & 1700 & 3450 & 3000 & $-\cdots--$ \\
$4 \%$ perlite, 1\% Bento. & 2000 & 3400 & 2450 & 3200 \\
$4 \%$ gilsonite & 4300 & 6650 & 4650 & 3700 \\
$5 \%$ sepiolite & 5400 & 6000 & 8010 & 2700 \\
Ct.J:F.A. 73:27 & 3000 & $-\cdots$ & 7100 & 6550 \\
\hline
\end{tabular}


the beneficial effect of the $\mathrm{Al}_{2} \mathrm{O}_{3}$ at $175^{\circ}$ and $250^{\circ} \mathrm{C}\left(346^{\circ}\right.$ and $\left.482^{\circ} \mathrm{F}\right)$ on strength, noted previously. In this test, the $345^{\circ} \mathrm{C}\left(653^{\circ} \mathrm{F}\right)$ strength remained high, although significant strength loss generally occurs at this temperature.

The Class $\mathrm{J}$ cement without $\mathrm{Al}_{2} \mathrm{O}_{3}$ addition had been reported to give moderately high strength at $150^{\circ}$ or $175^{\circ} \mathrm{C}\left(302^{\circ}\right.$ or $\left.346^{\circ} \mathrm{F}\right)$ in 1- to 7 -day curing. Subsequent curing at $225^{\circ} \mathrm{C}$ of companion specimens caused a large strength 10 ss. Repeat tests on another sample of cement falled to show the strength loss. Two factors were suspected: (a) difference in the amount of scawtite formation, and (b) difference in $\mathrm{W} / \mathrm{S}$ ratio. The latter was tested by using $\mathrm{W} / \mathrm{S}$ ratios of 0.45 and 0.70 . The $0.70 \mathrm{~W} / \mathrm{S} \mathrm{mix}$ was precured at $100^{\circ} \mathrm{C}$ for $24 \mathrm{hr}$ to thicken the slurry. Both slurries were cured for 1 day at $150^{\circ} \mathrm{C}\left(302^{\circ} \mathrm{F}\right)$ and then for 1,3 , and 7 days at $225^{\circ} \mathrm{C}\left(437^{\circ} \mathrm{F}\right)$. As seen in Table 4 , the $0.70 \mathrm{~W} / \mathrm{S}$ specimens underwent large strength 1 oss at $225^{\circ} \mathrm{C}\left(437^{\circ} \mathrm{F}\right)$, but the $0.45 \mathrm{~W} / \mathrm{S}$ specimens did not. It follows that the $W / S$ ratio may have a significant effect on the tobermorite to xonotlite transformation. Obviously, the strength loss of more extended slurries would even be more drastic. The strength loss accompanying the tobermorite to xonotlite transformation is a factor for further consideration.

The search for a modified $J$ cement composition showing promise with regard. to strength, volume stability, bond strength, and saline water resistance indicated a composition of $0.65 \mathrm{C} /(\mathrm{S}+3 \mathrm{~A})-\mathrm{J}$. The effects on strength of 0 to $5 \%$ $\mathrm{Al}_{2} \mathrm{O}_{3}$ and other additions, principally accelerators, were tested (Table 5). With all additions of $\mathrm{Al}_{2} \mathrm{O}_{3}$, the strength tended to be relatively high at all temperatures. The $3 \% \mathrm{Al}_{2} \mathrm{O}_{3}$ addition was selected as an optimum (higher ones tended to increase shrinkage). Additions of salts and $\mathrm{Fe}_{2} \mathrm{O}_{3}$ had no significant effect on the selected compositions. Extenders, except perlite at $150^{\circ} \mathrm{C}$, also gave satisfactory results in normal-weight cements. The strengths were always higher at $250^{\circ} \mathrm{C}\left(482^{\circ} \mathrm{F}\right)$ than at $345^{\circ} \mathrm{C}\left(653^{\circ} \mathrm{F}\right)$ because of A-Tobermorite formation. The strengths at $175^{\circ} \mathrm{C}\left(346^{\circ} \mathrm{F}\right)$ were also generally high with respect to strength, the $0.65 \mathrm{C} /(\mathrm{S}+3 \mathrm{~A})-\mathrm{J}$ cement performed very well at normal weight.

The $1.0 \mathrm{C} / \mathrm{S}-\mathrm{J}$ cement and modifications also performed well at normal weight. In tests on extended slurries, this cement did not appear satisfactory at $150^{\circ} \mathrm{C}$. A composition containing $8 \%$ perlite and $2 \%$ bentonite, at $12.31 \mathrm{~b} / \mathrm{gal}$ density, was tested with precures at $23^{\circ} \mathrm{C}\left(73^{\circ} \mathrm{F}\right)$ and $150^{\circ} \mathrm{C}\left(302^{\circ} \mathrm{F}\right)$, in 1 - and $2-i n$. cubes. Table 6 shows that strengths after precure were entirely unsatisfactory, but the results at $250^{\circ} \mathrm{C}$ and $345^{\circ} \mathrm{C}$ were satisfactory.

Representative results for light-weight $0.65 \mathrm{C} /(\mathrm{S}+3 \mathrm{~A})$. cements extended with $8 \%$ perlite and $2 \%$ bentonite are shown in Table 7 . The mixes without gypsum in two separate tests gave very poor results. Additions of gypsum overcame the weakness at a 17 temperatures. Since this composition with 2 to $6 \%$ gypsum was considered a highly promising candidate as a geothermal we 11 cement, larger mixes were prepared with 3 and $6 \%$ gypsum for 1 - and $2-i n$. cubes, $1 \times 1 \times 5-i n$. bars, and bond strength specimens. In direct contrast and for an unknown reason, both these mixes gave very poor results compared with those of the smaller mixes. The results for the 6\% gypsum addition are given at the end of Table 7 . Since these were the final tests in the series, and the needed follow-up experiments could not be done, other results were resorted to in order to explain the zero strength at $345^{\circ} \mathrm{C}\left(653^{\circ} \mathrm{F}\right)$.

In earlier chemical research on truscottite ${ }^{6}$ compositions of 0.6 and 0.6 $c(S+A)$ of quicklime, silicic acid, and gibbsite in slurries of $5.0 \mathrm{w} / \mathrm{S}$ yielded 
Table 4

Compressive Strength of Class $\mathrm{J}$ Cement at 0.45 and $0.70 \mathrm{C} / \mathrm{S}$

\begin{tabular}{|c|c|c|c|c|}
\hline \multirow[b]{3}{*}{$W / S$} & \multicolumn{4}{|c|}{ Strength, psi } \\
\hline & \multicolumn{4}{|c|}{$150^{\circ} \mathrm{C}$ Precure, then } \\
\hline & - & $225^{\circ} \mathrm{C}-1 \mathrm{~d}$ & $225^{\circ} \mathrm{C}-3 \mathrm{~d}$ & $225^{\circ} \mathrm{C}-7 \mathrm{~d}$ \\
\hline \multirow[t]{3}{*}{0.45} & 3750 & 4250 & 3000 & 4050 \\
\hline & \multicolumn{4}{|c|}{$100^{\circ} \mathrm{C}-1 \mathrm{~d}$, then $150^{\circ} \mathrm{C}-1 \mathrm{~d}$, then } \\
\hline & - & $225^{\circ} \mathrm{C}-1 \mathrm{~d}$ & $225^{\circ} \mathrm{C}-3 d$ & $225^{\circ} \mathrm{C}-7 \mathrm{~d}$ \\
\hline 0.70 & 2950 & 1000 & 1000 & 1300 \\
\hline
\end{tabular}

Table 5

Compressive Strengths of $0.65 \mathrm{C} /(\mathrm{S}+\mathrm{A})$ Cements

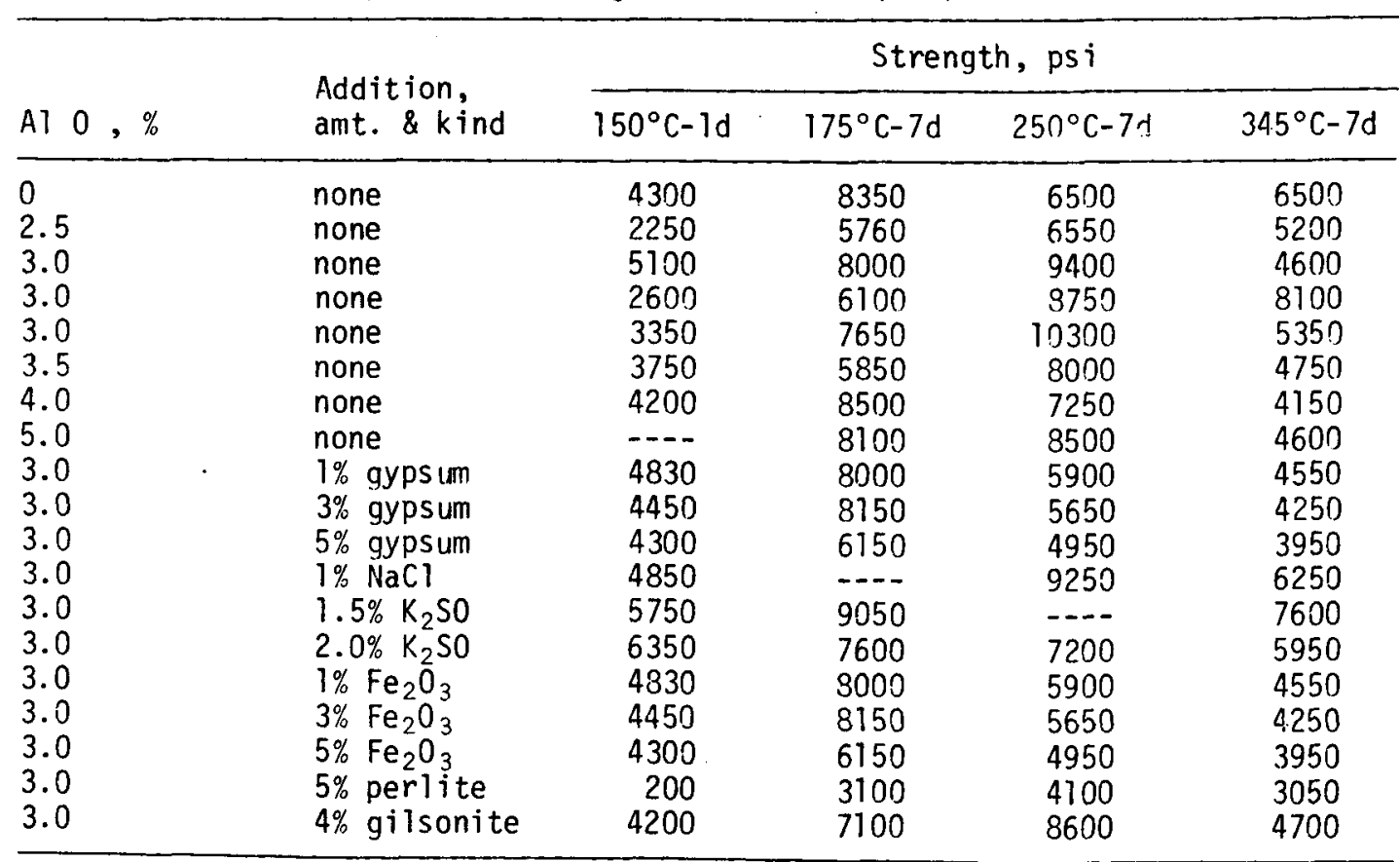


Table 6

Compressive Strength of Light-Density $1.0 \mathrm{C} / \mathrm{S}-\mathrm{G}$ Cements

\begin{tabular}{|c|c|c|c|c|c|}
\hline \multirow{2}{*}{$\begin{array}{l}\text { Slurry density, } \\
\text { lb/gal }\end{array}$} & \multirow{2}{*}{$\begin{array}{l}\text { Cube } \\
\text { size }\end{array}$} & \multicolumn{4}{|c|}{ Strength, psi } \\
\hline & & $23^{\circ} \mathrm{C}-7 \mathrm{~d}$ & $150^{\circ} \mathrm{C}-1 \mathrm{~d}$ & $250^{\circ} \mathrm{C}-7 \mathrm{~d}$ & $345^{\circ} \mathrm{C}-7 \mathrm{~d}$ \\
\hline 12.3 & 1 -in. & 0 & $-\ldots$ & 1650 & $-\ldots$ \\
\hline 12.3 & 2-in. & 130 & --- & 1800 & 2300 \\
\hline 12.3 & $1-$ in. & $\cdots$ & 80 & 1850 & $-\cdots$ \\
\hline 12.3 & $2-i n$. & $\cdots$ & 220 & 2250 & 2400 \\
\hline
\end{tabular}

Table 7

Compressive Strength of Light-Density $0.65 \mathrm{C} /(\mathrm{S}+3 \mathrm{~A})$ Cements

\begin{tabular}{|c|c|c|c|c|c|}
\hline \multirow{2}{*}{$\begin{array}{c}\text { Slurry weight, } \\
\text { Ib/gal }\end{array}$} & \multirow{2}{*}{$\begin{array}{l}\text { Addition, } \\
\text { amt. \& kind }\end{array}$} & \multirow{2}{*}{$\begin{array}{l}\text { Cube } \\
\text { size }\end{array}$} & \multicolumn{3}{|c|}{ Compressive strength, psi } \\
\hline & & & $150^{\circ} \mathrm{C}-1 \mathrm{~d}$ & $250^{\circ} \mathrm{C}-7 \mathrm{~d}$ & $345^{\circ} \mathrm{C}-7 \mathrm{~d}$ \\
\hline 11.4 & none & $1-i n$. & 0 & 550 & 250 \\
\hline 11.4 & none & i-in. & 0 & 750 & 200 \\
\hline 12.7 & $2 \%$ gypsum & l-in. & 2350 & 3600 & 3550 \\
\hline 12.7 & $4 \%$ gypsum & $i-i n$. & 2350 & 3850 & 4050 \\
\hline 12.7 & $6 \%$ gypsum & 1 -in. & 2300 & 4100 & 3550 \\
\hline 12.8 & $6 \%$ gyps um & $1-$ in. & 400 & $-\cdots$ & --- \\
\hline 12.8 & $6 \%$ gypsum & $2-i n$. & 690 & 3000 & 0 \\
\hline
\end{tabular}

Table 8

Compressive Strength and Phase Compositions of Cements Cured at $350^{\circ} \mathrm{C}$

\begin{tabular}{lccl}
\hline Cement & $\begin{array}{r}\text { Time at } \\
350^{\circ} \mathrm{C}-\mathrm{d}\end{array}$ & $\begin{array}{r}\text { Strength, } \\
\text { psi }\end{array}$ & Binder \\
\hline $0.6 \mathrm{C} / \mathrm{S}-\mathrm{J}$ & 7 & 3000 & Trusc. Scaw. \\
$0.6 \mathrm{C} / \mathrm{S}-\mathrm{J}$ & 30 & 3400 & Trusc. Scaw. \\
$0.6 \mathrm{C} / \mathrm{S}-\mathrm{J}$ & 90 & 3150 & Trusc. Scaw. (Xonot.) \\
$0.6 \mathrm{C} /(\mathrm{S}+5 \mathrm{~A})-\mathrm{J}$ & 7 & 3450 & Trusc. minor Scaw. \\
$0.6 \mathrm{C} /(\mathrm{S}+5 \mathrm{~A})-\mathrm{J}$ & 30 & 3350 & Trusc. minor Scaw. \\
$0.6 \mathrm{C} /(\mathrm{S}+5 \mathrm{~A})-\mathrm{J}$ & 90 & 3150 & Trusc. minor Scaw. (Xon.) \\
$0.6 \mathrm{C} / \mathrm{S}-\mathrm{G}$ & 7 & 7650 & Xon., Trusc., Q* \\
$0.6 \mathrm{C} / \mathrm{S}-\mathrm{G}$ & 30 & 7000 & Xon., Trusc., Q \\
$0.6 \mathrm{C} / \mathrm{S}-\mathrm{G}$ & 90 & 6600 & Xon., no Trusc., Q \\
\hline
\end{tabular}

*Residual quartz. 
apparently pure truscottite and presumably alumina-substituted truscottite. The A-Truscottite was soft and apparently of zero strength, whereas the truscottite exhibited some integration but was probably of low strength. Because of the importance of truscottite as an ultimate binder in geothermal wells, this research included actual strength tests in some detail.

Slurries of normal weight made of $0.6 \mathrm{C} / \mathrm{S}$ and $0.6 \mathrm{C} /(\mathrm{S}+5 \mathrm{~A})-\mathrm{J}$ cements were autoclaved at $350^{\circ} \mathrm{C}$ for 7,30 , and 90 days. Also, $0.6 \mathrm{C} / \mathrm{S}-\mathrm{G}$ cement was tes ted in a companion series. The results (Table 8) show strengths that are about the same and are satisfactory for both $J$ cement compositions at 7 to 90 days. Apparently the truscottite with and without $\mathrm{Al}_{2} \mathrm{O}_{3}$ was a satisfactory binder. The truscottite seemed to remain relatively stable through about 30 days. A small amount of xonotlite was detected at 90 days indicating that at $350^{\circ} \mathrm{C}$ the truscottite to xonotlite transformation was occurring, apparently quite slowly. In these tests, scawtite appeared to have no effect on the results.

The $0.6 \mathrm{C} / \mathrm{S}-\mathrm{G}$ cement specimens had much higher strengths than the $\mathrm{Cl}$ ass $\mathrm{J}$ cement compositions. A small decrease occurred between 7 and 90 days. At 7 days, the binder was essentially xonotlite with some truscottite. At 90 days, the truscottite was depleted and only xonotlite and residual quartz were found. In Cement $G$, the transformation of truscottite to xonotlite apparently had gone to completion at $350^{\circ} \mathrm{C}$.

It seemed worthwhile to compare the 90 day $-350^{\circ} \mathrm{C}\left(562^{\circ} \mathrm{F}\right)$ binder of $0.6 \mathrm{C} /(\mathrm{S}+\mathrm{A})-\mathrm{J}$ cement with the 7 day $-345^{\circ} \mathrm{C}\left(653^{\circ} \mathrm{F}\right)$ binder of the extended 0.6 $\mathrm{C} /(\mathrm{S}+3 \mathrm{~A})$ plus $6 \%$ gypsum of zero strength. Taylor ${ }^{14}$ reported that the binders of both were similar, consisting of truscottite, xonotlite, scawtite, and quartz. The crystals in the zero-strength light-weight product were coarse, up to $40 \mu \mathrm{m}$ in cross section, whereas those of the other binder at normal weight were much finer, $>10 \mu \mathrm{m}$. The air and water permeabilities of the zero-strength product were 3.0 and $2.5 \mathrm{md}$, respectively.

\section{B. Volume Change}

The volume change was determined to ascertain whether it was related to bond strength. Expansion of the cement in the annulus would induce a compressive stress in the cement and therefore increase the bond strength. Shrinkage would portend weakening or rupture of the bond. As mentioned, reference length of the bar was measured on the $150^{\circ} \mathrm{C}\left(302^{\circ} \mathrm{F}\right)$ precured specimen after it was conditioned in $23^{\circ} \mathrm{C}\left(73^{\circ} \mathrm{F}\right)$ water. The reported length changes at $250^{\circ} \mathrm{C}$ and $345^{\circ} \mathrm{C}\left(402^{\circ}\right.$ and $\left.653^{\circ} \mathrm{F}\right)$ were based on the reference length, and all measurements were made at $23^{\circ} \mathrm{C}\left(73^{\circ} \mathrm{F}\right)$.

The length changes of the $0.6,0.8$, and $1.0 \mathrm{C} / \mathrm{S}-\mathrm{G}$ cements at normal weight are given in "Table 9. The expansion of the $1.0 \mathrm{C} / \mathrm{S}-\mathrm{G}$ bars were 0.095 to $0.136 \%$ at $250^{\circ} \mathrm{C}\left(482^{\circ} \mathrm{F}\right)$ and 0.035 to $0.149 \%$ at $345^{\circ} \mathrm{C}\left(653^{\circ} \mathrm{F}\right)$. The expansion of the 0.6 and $0.8 \mathrm{C} / \mathrm{S}$ compositions was less than that of the $1.0 \mathrm{C} / \mathrm{S}$ compositions and decreased with increasing temperature. The bars with flyash shrank $0.097 \%$ at $345^{\circ} \mathrm{C}\left(653^{\circ} \mathrm{F}\right)$; addition of perlite increased the shrinkaqe to $0.21 \%$.

The length changes of the 0.6 to $1.0 \mathrm{C} / \mathrm{S}-\mathrm{J}$ cements are shown in Table 10 . Compositions at 0.65 and $0.85 \mathrm{C} / \mathrm{S}$ without additions expanded in the range of $0.13 \%$ at $250^{\circ} \mathrm{C}\left(482^{\circ} \mathrm{F}\right)$ and $0.10 \%$ at $345^{\circ} \mathrm{C}\left(653^{\circ} \mathrm{F}\right)$. In all tests, additions decreased expansions progressively with increasing temperature; at $345^{\circ} \mathrm{C}\left(653^{\circ} \mathrm{F}\right)$ 
Table 9

Length Change of $1.0 \mathrm{C} / \mathrm{S}-\mathrm{G}$ Cements

\begin{tabular}{lcc}
\hline & \multicolumn{1}{c}{ Length change, $\%$} \\
\cline { 2 - 3 } Addition, amt. \& kind & $250^{\circ} \mathrm{C}-7 \mathrm{~d}$ & $345^{\circ} \mathrm{C}-7 \mathrm{~d}$ \\
\hline none & +0.100 & +0.087 \\
none & +0.108 & +0.107 \\
$2 \% \mathrm{NaCl}$ & +0.113 & +0.100 \\
$4 \%$ gypsum & +0.136 & +0.149 \\
$5 \%$ perlite & +0.095 & +0.035 \\
$4 \% \mathrm{P}, 1 \% \mathrm{~B}, 4 \%$ gypsum & +0.098 & +0.097 \\
$6 \%$ Bento. & +0.090 & +0.075 \\
$6 \%$ Bento. $4 \%$ gypsum & +0.100 & +0.097 \\
$5 \%$ sepiolite & +0.098 & +0.056 \\
$4 \%$ gilsonite & +0.100 & +0.068 \\
$1.0 \mathrm{C} / \mathrm{S}-\mathrm{G}: \mathrm{F} . \mathrm{A} ., 56: 44$ & +0.048 & -0.097 \\
$1.0 \mathrm{C} / \mathrm{S}-\mathrm{G}: \mathrm{F} . \mathrm{A} ., 56: 44+4 \% \mathrm{P}+1 \% \mathrm{~B}$ & -0.066 & -0.217 \\
$(0.6 \mathrm{C} / \mathrm{S}-\mathrm{G}) \star$ & +0.046 & -0.008 \\
$0.8 \mathrm{C} / \mathrm{S}-\mathrm{G}) \star$ & +0.081 & +0.069 \\
\hline
\end{tabular}

*Note lower $\mathrm{C} / \mathrm{S}$.

\section{Table 10}

Length Change of $0.65,0.85$, and $1.0 \mathrm{C} /(\mathrm{S}+\mathrm{A})-\mathrm{J}$ Cements

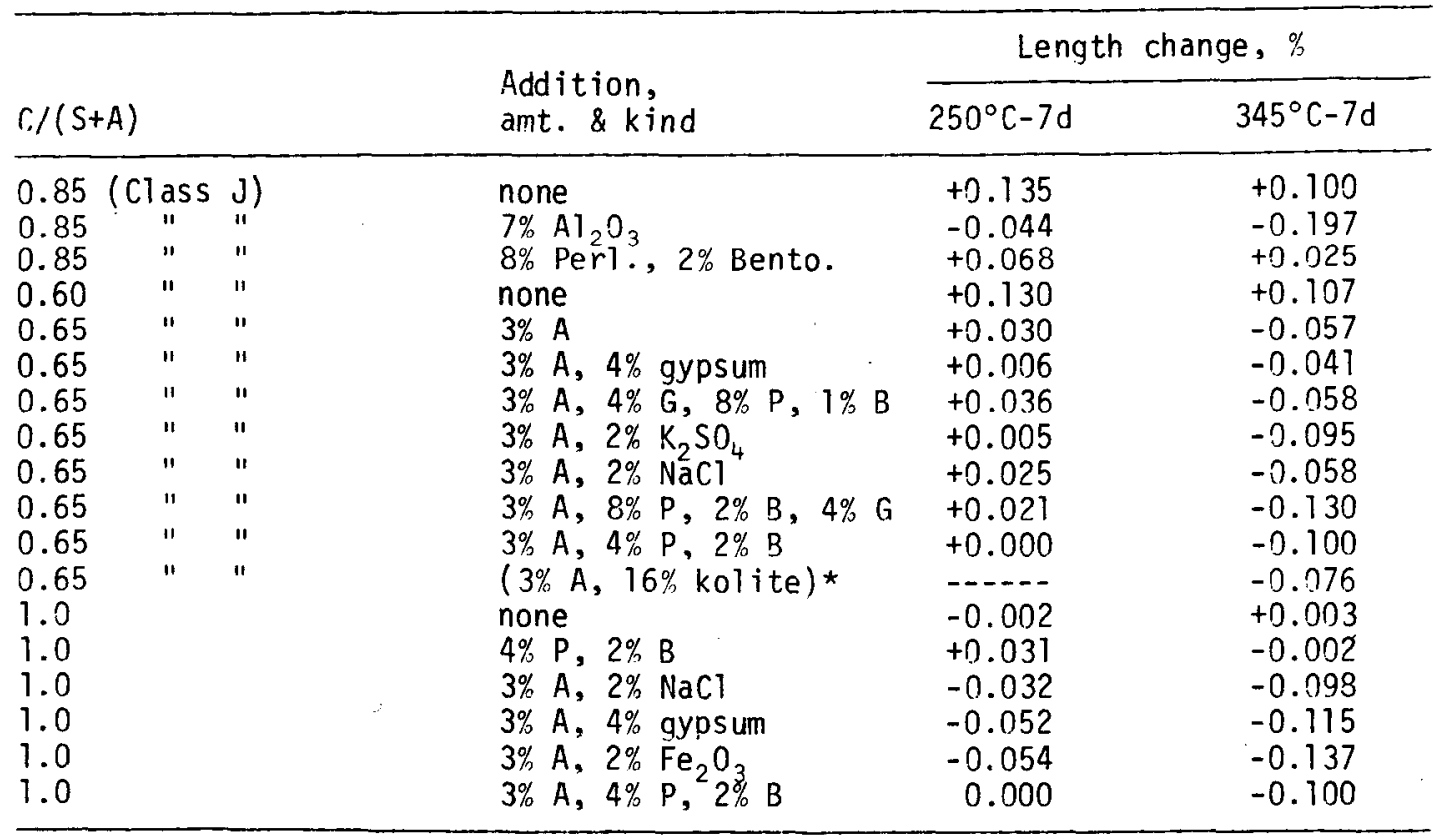

*Light-weight. 
the length changes ranged from -0.04 to $-0.13 \%$. The $1.0 \mathrm{C} / \mathrm{S}$ composition without addition underwent very little volume change at both temperatures. All additions to the $1.0 \mathrm{C} /(\mathrm{S}+3 \mathrm{~A})$ cements caused small to moderate volume changes at $250^{\circ} \mathrm{C}\left(472^{\circ} \mathrm{F}\right)$; at $345^{\circ} \mathrm{C}\left(653^{\circ} \mathrm{F}\right)$ the shrinkages were large: 0.10 to $0.14 \%$.

\section{Bond Strength}

$\mathrm{Class} \mathrm{J}$ and $\mathrm{G}$ cements and modifications were tested for bond strength to granite, sandstone, limestone, serpentine, basalt, and steel. Specimens of two shales failed in compression above the cement annulus before failure in shear could occur. The effect of a bentonite coating on the sandstone and basalt was also determined.

The bond strengths of normal-weight cements at $250^{\circ} \mathrm{C}\left(573^{\circ} \mathrm{F}\right)$ (Figure 3) were all very high, about 1000 to $2300 \mathrm{psi}(6890$ to $15,347 \mathrm{kPa})$ except those of the bentonite-coated specimens, which were in the range 100 to 250 psi (689 to $1723 \mathrm{kPa}$ ). Although none of these cements showed shrinkage, the bond strengths did not show a quantitative relation to volume change.

The bond strengths at $345^{\circ} \mathrm{C}\left(593^{\circ} \mathrm{F}\right)$ for both normal and light-weight cements (Figure 4) were much lower than at $250^{\circ} \mathrm{C}\left(572^{\circ} \mathrm{F}\right)$. Nonetheless, the normalweight cements had acceptable strengths. The light-weight cements showed low bond strengths in two of the six tests. These results indicate general correlation between bond strength and temperature of curing.

\section{Cement - Aggregate Fines Strengths}

The bond between cement and formation is due to a combination of chemical and mechanical binding. The bond between cement and steel is largely chemical provided the steel surface is free of blemishes. The compressive strengths of rock fines and cement might yield useful information regarding weakness (if any occurred) in the binders formed at the formation-cement interface.

A11 the strengths measured (Table 11) appeared satisfactory except those for the $1.0 \mathrm{C} / \mathrm{S}-G$ cement - shale $A$. The tests were repeated with shale $A$ and with another shale, designated $B$. The results with shale $A$ duplicated the earlier ones within reasonable limits, and those with shale $B$ were satisfactory for both cements. The compressive strengths did not reveal any poor bonding due to chemical reaction between formation and cement except in the case of shale A. The present results confirmed previous findings 7 that shales may vary in properties.

\section{E. Saline Water Tests}

Selection of a saline water composition representative of waters in geothermal wells was impractical because the brines may contain many salts and vary widely in composition. Previous research ${ }^{4}$ on effects of sodium salts showed that carbonate and sulfate could cause deterioration of calcium silicate hydrates but chloride apparently had no such effect. The saline solution selected for the present tests consisted of $0.5 \mathrm{M} \mathrm{Na}_{2} \mathrm{SO}_{4}$ and $0.5 \mathrm{M} \mathrm{Na}_{2} \mathrm{CO}_{3}$, about $5 \%$ solids by weight of solution. 


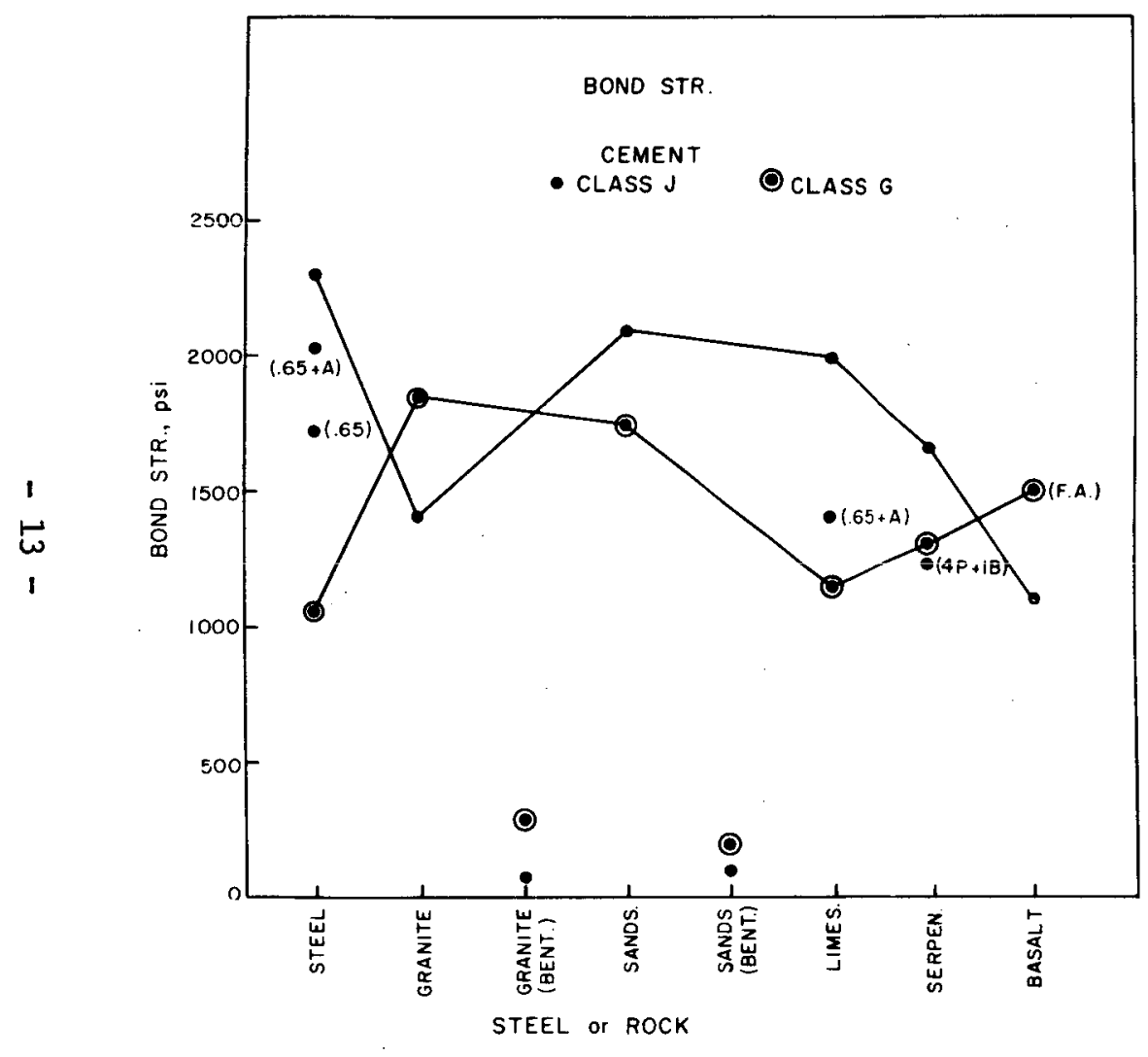

Figure 3. Bond strength of cement to steel and rock at $250^{\circ} \mathrm{C}$.

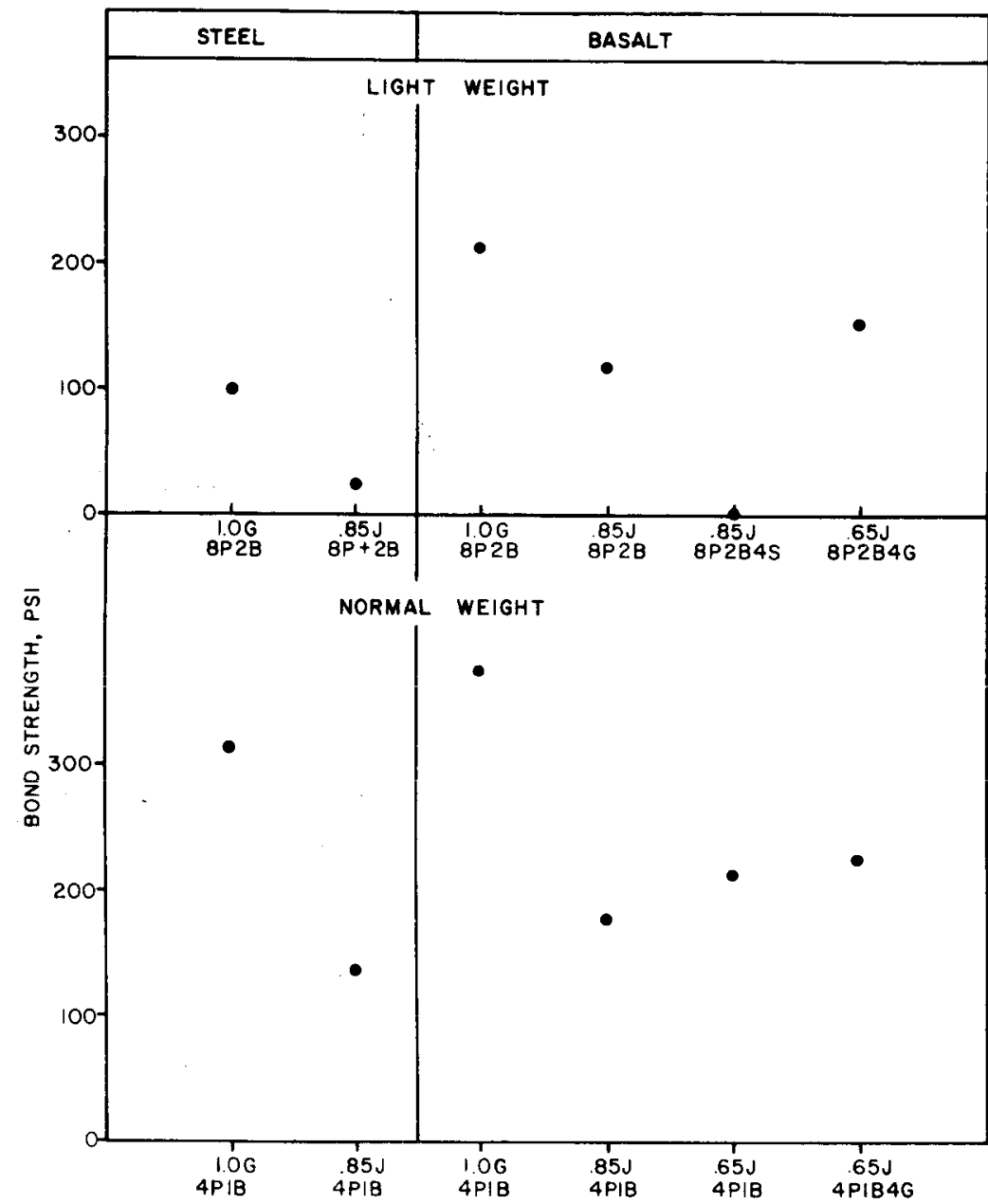

Figure 4. Bond strength of light-weight and normal-weight cements to steel and basalt at $345^{\circ} \mathrm{C}$. 


\begin{tabular}{|c|c|c|c|}
\hline \multicolumn{4}{|c|}{ Table 11} \\
\hline \multicolumn{4}{|c|}{ Strengths of Formation Fines and Cements $\mathrm{J}$ and $\mathrm{G}(50: 50)$} \\
\hline \multirow{2}{*}{$\begin{array}{l}\text { Formation } \\
\text { fines }\end{array}$} & \multirow[b]{2}{*}{ Time \& temp. } & \multicolumn{2}{|c|}{ Compressive strength, psi } \\
\hline & & Cement $\mathrm{J}$ & Cement G \\
\hline Granite & $1 d-150^{\circ} \mathrm{C}$ & 2550 & 4250 \\
\hline Granite & $7 \mathrm{~d}-175^{\circ} \mathrm{C}$ & 3950 & 3000 \\
\hline Granite & $7 \mathrm{~d}-250^{\circ} \mathrm{C}$ & 4300 & 6800 \\
\hline Granite & $7 d-350^{\circ} \mathrm{C}$ & 2400 & 4400 \\
\hline Sandstone & $1 \mathrm{~d}-150^{\circ} \mathrm{C}$ & 3100 & 5600 \\
\hline Sandstone & $7 \mathrm{~d}-175^{\circ} \mathrm{C}$ & 3450 & 5950 \\
\hline Sands tone & $7 \mathrm{~d}-250^{\circ} \mathrm{C}$ & 4600 & 2800 \\
\hline Sandstone & $7 \mathrm{~d}-350^{\circ} \mathrm{C}$ & 2300 & 2750 \\
\hline Dolomite & $1 \mathrm{~d}-150^{\circ} \mathrm{C}$ & 1900 & 2000 \\
\hline Dolomi te & $7 d-175^{\circ} \mathrm{C}$ & 2600 & 1100 \\
\hline Dolomite & $7 d-250^{\circ} \mathrm{C}$ & 4350 & 1850 \\
\hline Dol omi te & $7 \mathrm{~d}-350^{\circ} \mathrm{C}$ & 2050 & 3500 \\
\hline Shale (A) & $1 d-150^{\circ} \mathrm{C}$ & $2500(2450) *$ & $1550(1450)$ \\
\hline Shale (A) & $7 \mathrm{~d}-175^{\circ} \mathrm{C}$ & $2850(3200)$ & $1000(950)$ \\
\hline Shale (A) & $7 \mathrm{~d}-250^{\circ} \mathrm{C}$ & $4000(3100)$ & $1250(1300)$ \\
\hline Shale (A) & $7 d-350^{\circ} \mathrm{C}$ & $2300(3450)$ & $2000(1600)$ \\
\hline Sha le (B) & $1 \mathrm{~d}-150^{\circ} \mathrm{C}$ & 1350 & 2800 \\
\hline Shale (B) & $7 d-175^{\circ} \mathrm{C}$ & 4200 & 2450 \\
\hline Shale (B) & $7 d-250^{\circ} \mathrm{C}$ & 4900 & 4850 \\
\hline Shale (B) & $7 d-350^{\circ} \mathrm{C}$ & 1800 & 2750 \\
\hline
\end{tabular}

*Values in parantheses are for duplicate runs. 


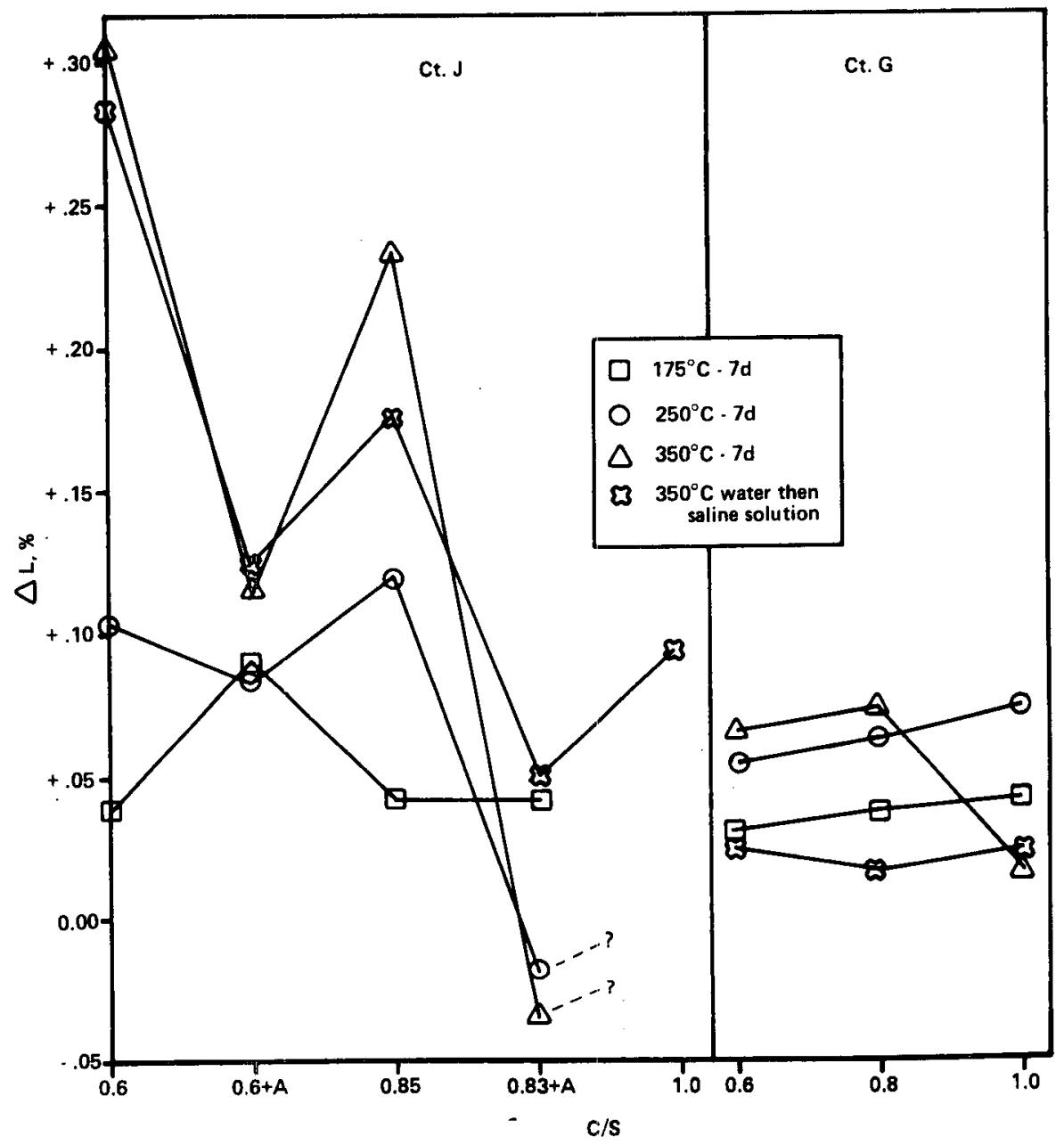

Figure 5. Length changes of modifications of $\mathrm{Class} \mathrm{J}$ and Class $G$ cements in saline solution. 
Test specimens were $1 \times 1 \times 5-i n$. bars for volume change and $1-i n$. cubes for strength. Modifications of $\mathrm{Cl}$ ass $\mathrm{G}$ and $\mathrm{Cl}$ ass $\mathrm{J}$ cements were exposed for 7 days at $175^{\circ}, 250^{\circ}$, and $350^{\circ} \mathrm{C}\left(345^{\circ}, 482^{\circ}\right.$, and $662^{\circ} \mathrm{F}$ ) (Figure 5). The $0.6 \mathrm{C} / \mathrm{S}-\mathrm{J}$ cement showed increasing expansion with increasing temperature, up to $0.3 \%$ at $345^{\circ} \mathrm{C}\left(653^{\circ} \mathrm{F}\right)$. So high an expansion in 7-day exposure could portend more expansion in long-time tests. The companion composition of $0.6 \mathrm{C} /(\mathrm{S}+\mathrm{A})$ with $5 \%$ $\mathrm{Al}_{2} \mathrm{O}_{3}$ showed small difference between $175^{\circ}$ and $350^{\circ} \mathrm{C}\left(346^{\circ}\right.$ and $\left.662^{\circ} \mathrm{F}\right)$, indicating a positive effect of $\mathrm{Al}_{2} \mathrm{O}_{3}$ on reducing expansion. Cement $\mathrm{Cl}$ ass $\mathrm{J}$ at 0.85 $\mathrm{C} / \mathrm{S}$ showed a trend similar to that of the $0.6 \mathrm{C} / \mathrm{S}$ composition. The companion composition of $0.83 \mathrm{C} /(\mathrm{S}+\mathrm{A})$ with $7 \% \mathrm{Al}_{2} \mathrm{O}_{3}$ showed a marked reduction of expansion, down to a shrinkage of $0.03 \%$ at $350^{\circ} \mathrm{C}\left(662^{\circ} \mathrm{F}\right)$; this composition showed a large shrinkage, $0.2 \%$, in water. It follows that $\mathrm{Al}_{2} \mathrm{O}_{3}$ has a stabilizing effect on volume change in saline solution. The $1.0 \mathrm{C} / \mathrm{S}-\mathrm{J}$ cement containing xonotlite as binder showed a moderate expansion at $350^{\circ} \mathrm{C}\left(662^{\circ} \mathrm{F}\right)$.

The volume changes of the 0.6 to $1.0 \mathrm{C} / \mathrm{S}-\mathrm{G}$ cements in saline water were small expansions at all temperatures, reflecting again the possible favorable behavior of xonotlite as binder in these cements.

The compressive strengths of the Class $\mathrm{J}$ cement compositions exhibited no unusual behavior compared with that in water. The strength of the cement $G$ composition increased with increasing $\mathrm{C} / \mathrm{S}$ ratio at $250^{\circ}$ and $345^{\circ} \mathrm{C}\left(472^{\circ}\right.$ to $\left.653^{\circ} \mathrm{F}\right)$, but decreased at $175^{\circ} \mathrm{C}\left(346^{\circ} \mathrm{F}\right)$. All results, however, appeared satisfactory. The strengths did not correlate with the volume changes shown in Figure 5 , nor did they reflect any significant effect (if any) of $\mathrm{Al}_{2} \mathrm{O}_{3}$ addition.

Additional volume change results on light-weight cements exposed to the saline solution for 14 days at $300^{\circ} \mathrm{C}\left(572^{\circ} \mathrm{F}\right)$ are shown in Table 12 . The changes were generally small. The $56 \mathrm{CtG}: 44$ flyash without and with $4 \%$ perlite plus $1 \%$ bentonite at normal weight underwent shrinkages of 0.17 and $0.16 \%$, respectively. These volume changes are of the same magnitude as those observed for water curing.

\section{F. Thickening Time}

Thickening times were measured on the $0.65 \mathrm{C} /(\mathrm{S}+\mathrm{A})-\mathrm{J}$ cement compositions and variations which had appeared promising (Table 13). The test was conducted-according to API Thickening Time Test, schedule No. 30. A11 mixes were extended with $8 \%$ perlite plus $2 \%$ bentonite by weight of the $\mathrm{BC}_{2} \mathrm{~S}$ ( $69 \%$ in Class $\mathrm{J}$ cement). The gypsum addition was made on this basis also.

Cement No. 1 (Table 13) gave an erratic consistometer recording because of deposition of solids on the instrument paddle. When the test was terminated at 165 min, the slurry had thickened considerably. Cement No. 2 was the same as No. 1 except that the gypsum was reduced to $2 \%$. This proved to be too great a reduction; at 360 min the slurry was still fluid. In run No. 3, the $\mathrm{Al}_{2} \mathrm{O}_{3}$ was decreased to $1.5 \%$ and the gypsum to $2 \%$. At $40 \mathrm{~min}$, the slurry was thickening rapidly. Run No. 4 was a repeat of No. 1. The cement was undergoing rapid stiffening after 45 min when the test was terminated.

Run No. 5 was a repeat of No. 1 (and No. 4) but with the addition of $0.5 \%$ calcium lignosulfonate. The thickening time of 169 min was considered satisfactory. 
Table 12

Linear Change of Cements in Saline Solution at $300^{\circ} \mathrm{C}$ for $14 \mathrm{~d}$

\begin{tabular}{|c|c|c|c|}
\hline Cement & Addition & $\begin{array}{l}\text { Slurry } \\
\text { density }\end{array}$ & Length change, \\
\hline $\begin{array}{l}0.65 \mathrm{C} /(\mathrm{S}+3 A)-\mathrm{J} \\
0.65 \mathrm{C} /(\mathrm{S}+3 A)-\mathrm{J} \\
0.65 \mathrm{C} /(\mathrm{S}+3 A)-\mathrm{J} \\
0.65 \mathrm{C} /(\mathrm{S}+1.5 \mathrm{~A})-\mathrm{J} \\
1.0 \mathrm{C} / \mathrm{S}-\mathrm{G} \\
56 \mathrm{Ct} . \mathrm{G}: 44 \mathrm{~F} . \mathrm{A} . \\
56 \mathrm{Ct} . \mathrm{G}: 44 \mathrm{~F} . \mathrm{A} . \\
1.0 \mathrm{C} / \mathrm{S}-\mathrm{G}\end{array}$ & 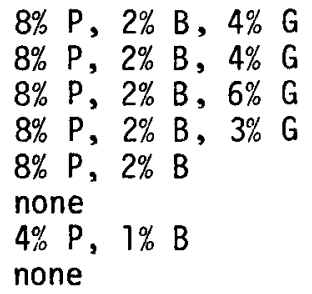 & $\begin{array}{l}\text { light } \\
\text { light } \\
\text { light } \\
\text { light } \\
\text { light } \\
\text { norma } 1 \\
\text { normal } \\
\text { normal }\end{array}$ & $\begin{array}{l}-0.010 \\
-0.029 \\
+0.069 \\
+0.060 \\
+0.045 \\
-0.172 \\
-0.160 \\
+0.107\end{array}$ \\
\hline
\end{tabular}

Table 13

Thickening Time Tests of Slurries at 12 lb/gal

\begin{tabular}{lll}
\hline No. & \multicolumn{1}{c}{ Cement Composition } & \multicolumn{1}{c}{ Results } \\
\hline 1. & $0.65 \mathrm{C} /(\mathrm{S}+\mathrm{A}), 3 \% \mathrm{~A}, 8 \% \mathrm{P}, 2 \% \mathrm{~B}, 4 \% \mathrm{G}$ & $\begin{array}{l}\text { Erratic reading. Significant } \\
\text { thickening in } 2 \mathrm{hr} 45 \mathrm{~min}\end{array}$ \\
2. & $0.65 \mathrm{C} /(\mathrm{S}+\mathrm{A}), 3 \% \mathrm{~A}, 8 \% \mathrm{P}, 2 \% \mathrm{~B}, 2 \% \mathrm{G}$ & $\begin{array}{l}\text { No significant thickening in } \\
6 \mathrm{hr}\end{array}$ \\
3. & $0.65 \mathrm{C} /(\mathrm{S}+\mathrm{A}), 1.5 \% \mathrm{~A}, 8 \% \mathrm{P}, 2 \% \mathrm{~B}, 2 \% \mathrm{G}$ & $\begin{array}{l}\text { Rapid stiffening at } 40 \mathrm{~min} \\
\text { Rapid stiffening at } 45 \text { min } \\
\text { Thickening normat, time } 169 \\
\text { min }\end{array}$ \\
\hline 5. & Repeat No. 1 with $0.5 \% \mathrm{CLS}$ & \\
\hline
\end{tabular}

\section{DISCUSSION AND INTERPRETATIONS}

\section{A. Strength}

Attempts to relate kinds of binder to strength were only partially successful. The problems relating to the chemical equilibria were more complex than anticipated. Obtaining long-time results in accelerated short-time laboratory tests was handicapped by slow attainment of equilibrium, formation of persistent metastable phases, and the possible growth of crystals of equilibrium phases with a disrupting effect on strength. The results obtained, even though incomplete, give some clear indications of directions for further research. The problems encountered appear to be resolvable.

Tobermorite has been frequently found as the binder in oil well cements consisting of portland cement and silica. Xonotlite has also been found as the binder, depending on temperature and other factors as observed in this research. 
Tobermorite, without extraneous components, is stable up to $150^{\circ} \mathrm{C}\left(302^{\circ} \mathrm{F}\right)$. At higher temperatures it breaks down into xonotlite plus either gyrolite or silica. The possibility of serious strength loss due to this transformation was investigated. Tobermorite, however, can accommodate substituent $\mathrm{Al}^{3+}$ in its structure with improvement both of temperature stability up to $250^{\circ} \mathrm{C}\left(472^{\circ} \mathrm{F}\right)$ or higher and of strength by 50 to $100 \%$. A temperature of $250^{\circ} \mathrm{C}\left(472^{\circ} \mathrm{F}\right)$ or higher would cover the temperature range in most oil and gas wells and a major part of the range in geothermal wells.

The tests on A-Tobermorite at $250^{\circ} \mathrm{C}\left(472^{\circ} \mathrm{F}\right)$ showed that curing for 7 and 28 days yielded the same phase and gave the same high strength. The rapidity at which A-Tobermorite forms and crystallizes at $250^{\circ} \mathrm{C}\left(472^{\circ} \mathrm{F}\right)$ permits the assumption that equilibrium was attained in 7 days. The $x$-ray diffraction patterns revealed the same crystallinity at both 7 and 28 days. The possibility that A-Tobermorite may be a long-range stable phase at temperatures up to $250^{\circ} \mathrm{C}$ $\left(472^{\circ} \mathrm{F}\right)$ or higher is clearly indicated. Although a conclusion cannot be drawn, the results point to a promising area of research, the success of which would mean that a large temperature range in hot oil, gas, and geothermal wells could be serviced with A-Tobermorite.

Attempts to develop truscottite as a high temperature binder were stimulated by the knowledge that this phase may form over a broad range of high temperatures. Cements of usual compositions, about 0.6 to $1.0 \mathrm{c} / \mathrm{S}$, react with silica to form truscottite at temperatures between about $220^{\circ}$ and $325^{\circ} \mathrm{C}\left(428^{\circ}\right.$ and $\left.617^{\circ} \mathrm{F}\right)$. The silica at the cement-formation interface would be available from many formations. In time, the truscottite, which might form slowly, would be the major factor in the bond strength.

The earlier synthesis 1,6 of truscottite with and without $\mathrm{Al}_{2} \mathrm{O}_{3}$ using quicklime, silicic acid, gibbsite, and a W/S ratio of 5.0 gave a striking result. The aluminous products, although essentially pure truscottite, developed no significant strength. It was thought that the low strength of the truscottite could be due to one or more of three factors: (1) high silica concentration in solution due to the silicic acid, (2) substitution of the $\mathrm{Al}^{3+}$ in the truscottite structure, or (3) growth of the initially formed truscottite crystals due to the high porosity of the mix.

The potential importance of truscottite prompted a detailed investigation. The results, already mentioned, on the $0.6 \mathrm{C} / \mathrm{S}$ and $0.60 \mathrm{C} /(\mathrm{S}+5 \mathrm{~A})$ cements at normal weights showed that the $\mathrm{Al}^{3+}$ in the structure had no detectable relation to strength. Solubility studies on truscottite and other calcium silicate hydrates failed to supply any clue on the low strengths. The relation between the crystal size of truscottite in binders of high and of zero strength suggested that strength retrogression of truscottite could be due to growth of crystals. This hypothesis is supported by results obtained by Eilers and Root ${ }^{13}$. Prolonged autoclaving of a cement of low C/S ratio at $232^{\circ} \mathrm{C}$ was accompanied by a large strength retrogression and increased porosity of the binder shown by $x$-ray diffraction to be a truscottite-like phase.

The uncertainty of tobermorite and truscottite as high temperature binders for long-time service directs attention to xonotilte and scawtite as possible alternative binders. Not much is known about scawtite as a cement, but chemical equilibrium studies ${ }^{5}$ showed that scawtite, depending on the amount of $\mathrm{CO}_{2}$ in the cement, may displace xonotlite partially or totally at $150^{\circ}$ to $300^{\circ} \mathrm{C}\left(302^{\circ}\right.$ to $\left.572^{\circ} \mathrm{F}\right)$. 
The option is, therefore, open of having xonotite or scawtite or a mixture of the two as binder. Research is underway elsewhere on the potential of scawtite.

The potential for long-time service of xonotlite, alone or modified by extraneous components, is not definitely known. A composition of $1.0 \mathrm{c} / \mathrm{s}$ yields xonotlite readily. In the absence of excess silica, xonotlite transforms to wollastonite (CS) at a temperature of $350^{\circ} \mathrm{C}\left(662^{\circ} \mathrm{F}\right)$ and saturated steam pressure ${ }^{14}$. The evaluation of xonotlite and wollastonite for long-time service should be feasible without difficulty. The need to learn why xonotlite imparts high strength at $345^{\circ} \mathrm{C}\left(653^{\circ} \mathrm{F}\right)$ to Class $\mathrm{G}+$ silica cement and moderate to low strength to modified Class $J$ cement is self-evident. Xonotlite has generally given satisfactory strength, but a recent finding by Gallus, et a 7.15 suggests the need for research on its strength retrogression. They exposed a lightweight composition of Cement $G+40 \%$ silica $+1 \mathrm{cu} f t$ perlite $+3 \%$ gel and admixtures, with xonotlite and calcite as binders, to Imperial Valley/Baca brines. At six months, the strength was satisfactory (2000 psi), but it retrogressed to zero in one year. This appears to be a meaningful result because the binder remained the same while the strength fell to zero. The first speculation, that the retrogression was caused by the originally formed xonotlite crystals growing in size between six months and one year, can be readily probed, and it deserves attention in any serious consideration of xonotlite as a longtime binder of geothermal well cements.

The temperature stability of truscottite with and without extraneous components has remained undetermined in previous studies. A recent program in which Taylor and associates at Aberdeen University are cooperating with the Colorado School of Mines is in progress to resolve this question. A tentative finding, awaiting further confirming results, is that the reaction truscottite $\rightarrow$ xonotlite plus silica occurs (under as yet undefined conditions) at a temperature much lower than $325^{\circ} \mathrm{C}\left(617^{\circ} \mathrm{F}\right)$. This research deserves pursuit to a satisfactory conclusion. Technologically, it appears highly significant.

The results of studies reviewed here include some viable evidence that growth of its crystals may be the cause of strength retrogression of truscottite. The same suspicion, based on meager information, may apply to strength retrogression of xonotlite.

\section{B. Volume Change}

In interpreting the volume-change data, it must be recognized that the measurements were made at $23^{\circ} \mathrm{C}\left(73^{\circ} \mathrm{F}\right)$ and the results do not represent the actual length change of the bars at the exposure temperature. Also, since the reference length was measured on bars precured at $150^{\circ} \mathrm{C}\left(302^{\circ} \mathrm{F}\right)$, the results do not include whatever volume change occurred between $23^{\circ} \mathrm{C}\left(73^{\circ} \mathrm{F}\right)$ and $150^{\circ} \mathrm{C}\left(302^{\circ} \mathrm{F}\right)$. In earlier tests, measurements made at $175^{\circ} \mathrm{C}\left(347^{\circ} \mathrm{F}\right)$ showed expansions of 0.02 to $0.05 \%$ over this $24^{\circ} \mathrm{C}$ interval. Visual examination of the precured molds and contents indicated that expansion had occurred, but the amount of expansion could not be deduced with certainty. It is concluded that the actual expansions at the exposure temperature were substantially larger than reported, and the shrinkages were less than reported. 


\section{Bond Strength}

The expected correlation of bond strength to volume change was not realized quantitatively. A general trend of decreased expansion and decreased bond strength was observed in going from $250^{\circ} \mathrm{C}\left(473^{\circ} \mathrm{F}\right)$ to $345^{\circ} \mathrm{C}\left(653^{\circ} \mathrm{F}\right)$. Two factors militated against a quantitative correlation: (1) as mentioned, the actual expansions at the exposure temperatures were higher than measured and the shrinkages less, and (2) the difference between the coefficient of thermal expansion of the metal and that of the cement or rock and cement affected the bond strength.

Despite the limitations of the test, the very high bond strengths generally obtained indicate that expansion of the cements has a beneficial effect on bonding.

\section{Saline Water Tests}

The work on effects of saline water on the cements was considered to be preliminary. The results indicated no serious changes in quality of the cements. $\mathrm{Al}_{2} \mathrm{O}_{3}$ additions to modified $\mathrm{Class} \mathrm{J}$ cements were found to decrease expansion compared with that of the same cement without $\mathrm{Al}_{2} \mathrm{O}_{3}$.

As shown previous $1 y^{4}$, carbonate and sulfate are destructive of calcium silicate hydrate by forming calcite and anhydride, respectively, and a sodium calcium silicate gel. To be destructive, the $\mathrm{CO}_{3}{ }^{2-}$ and $\mathrm{SO}_{4}{ }^{2-}$ must penetrate into the interior of the specimen and must form reaction products having little or no cementitious value. The exact mechanism is amenable to resolution by research, but direct tests of cements in the brine of actual geothermal wells provide a more rewarding approach. Such tests are being done by Dowell and also by Union $0 i 1$ and Halliburton Research. The results being obtained will supply answers to questions that cannot be readily and fully obtained by laboratory experimentation.

\section{E. Thickening Time}

The thickening times in API test schedule 30 of the $0.65 \mathrm{C} /(S+A)-\mathrm{J}$ cement modifications were either too slow or too fast. Addition of $0.5 \%$ calcium 1 ignosulfonate to one of the cements gave a satisfactory thickening time. The results, however, indicated that controlled amounts of gypsum and $\mathrm{Al}_{2} \mathrm{O}_{3}$ could give a satisfactory thickening time without an organic admixture.

\section{F. Permeability}

Permeability was obtained on one cement that showed zero strength at $345^{\circ} \mathrm{C}$ $\left(653^{\circ} \mathrm{F}\right)$. The permeability was very high. This was attributed to growth of the crystals of the binder. 


\section{SUMMARY AND CONCLUSIONS}

In the present research, no insurmountable difficulties were encountered with selected normal-weight portland cement-silica and $\mathrm{BC}_{2} \mathrm{~S}$-silica cements. Similar cements in light-weight slurries showed, on the basis of accelerated tests, possible long-term retrogression for two of the three ultimate binders. Al uminous tobermorite indicated long-term stability up to $250^{\circ} \mathrm{C}\left(472^{\circ} \mathrm{F}\right)$ or higher. Truscottite at normal weight appeared stable through 90 days at $350^{\circ} \mathrm{C}$ $\left(652^{\circ} \mathrm{F}\right)$. In a light-weight cement having a binder comparable with that of the normal-weight product, the strength retrogressed to zero in 7 days at $350^{\circ} \mathrm{C}$. Xonotlite as a principal binder exhibited strengths ranging from the highest to mediocre, and questions arose regarding this variability. Some limited published information indicated that light-weight xonotlite may undergo strength retrogression upon prolonged exposure to brine. Evidence on the performance of scawtite, as a fourth principal binder as a replacement for xonotlite, is still meager.

Directions for further research are discussed. It is evident that ultimate and positive evaluation of geothermal well cements established as satisfactory candidates in laboratory tests should be done under actual field conditions.

\section{REFERENCES}

1. G.L. Ka lousek and L.Y. Chaw, Paper SPE 5940, 51 st Annu. Tech. Conf. SPEAIME, New Orleans, Oct. 1976. (Abstract in SPE J. i6 307, Dec. 1976)

2. G.L. Kalousek, Cem. Concr. Res. 6, 417-18 (1976).

3. G.L. Kalousek, T. Mitsuda, and H.F.W. Taylor, Ibid. 7, 305-12 (1977).

4. E.B. Nelson and G.L. Kalousek, Ibid. 7, 687-97 (1977).

5. G.L. Kalousek and E.B. Nelson, Ibid. 3 , 283-90 (1978).

6. G.L. Kalousek, Factors affecting hydrothermal formation of hydrous calcium silicates, Proc. Int. Symp. on Lime-Sand Products, Karlsruhe, 1978.

7. D.K. Smith, Cementing, Monograph Vo 1. 4, Henry L. Doherty Series, SPE-AIME, 1976.

8. L.H. Eilers, E.B. Nelson, L.B. Spangle, D.L. Free, B.E. Simpson, and J.F. Williams, Development of Geothermal Well Completion Systems, Phase I Report, July-Sept. 1977, Dowe17 Div., Dow Chemical U.S.A., BNL/DOE Contract No. EG-77-C-02-4190.

9. A.Bezjak, Nature, 248, 581-83 (1974).

10. R.F. Feldman and J.J. Beaudoin, Cem. Concr. Res. 6, 389-400 (1976).

11. H.F.W. Taylor, Ibid. 7, 465-8 (1977). 
12. J.M. Crennan, S.A.S. El-Hemaly, and H.F.W. Taylor, Ibid. 7, 493-502 (1977).

13. L.H. Eilers and R.L. Root, Paper SPE 5028, 49th Annu. Fall Conf. SPE-AIME, Houston, Oct. 1974 .

14. H.F.W. Taylor, Personal communication, 1979.

15. J.P. Gallus, D.E. Pyle, and L.T. Watters, Paper SPE 7591, 53rd Annu. Fall Conf. SPE-AIME, Houston, Oct. 1978. 